\title{
Comparative Perception Among Minority Communities on the Knowledge of UN Convention of the Rights of Child, Institutional Responsibilities and Child Participation in Decision Making Processes
}

Nehare Zeqiraj

International Relation Specialist

\section{Executive summary}

The survey document is mandated to address two issues in Republic of Kosova as following:

I. Knowledge, Attitude and Practices of children and communities in relation to children rights and child protection in 5 Kosovo regions: Peja Gjakova, Ferizaj, Prizren and Fushe Kosovo

II. Evaluation of the communities knowledge on existing services in case of violations of the children rights in 5 Kosovo regions: Peja Gjakova, Ferizaj, Prizren and Fushe Kosovo

Specifically we attempt to answer the following questions by the Roma, Ashkali and Egyptians Children, parents and team leaders from the communities:

\section{Questionnaire for the children of RAE communities is as following:}

1. What rights do you think people should have?

2. What rights do you think Children should have?

3. What rights are most important for you?

4. What rights do you think you do not get?

5. Which people do not respect your rights? Can you give me an example?

6. Have you been told what your rights are and told them to you?

7. Have you told someone if your rights have not been respected? Whom did you tell in that situation? Which person you told? Whom would you tell in the future?

8. What more information would you like to know about your rights are?

9. What people do you know of that can help you in case your rights are violated?

10. What worries or issues do you have today?

11. What do you think should be done about this?

12. If you or your friends are/is abused / beaten, what would you do?

13. Is there anything else you would like to say?

\section{Questionnaire for the Team Leaders of RAE communities are as following:}

1. What do you understand with human rights?

2. What do you understand with children rights?

3. What is the basic human rights (how do you understand them)?

4. What do you think your responsibility is in the community?

5. Do you think that your rights are violated and by whom? (Please give an example when do you think your right is violated and by whom)?

6. Do you think as a Team Leader in the community has violated the right of you citizens (if yes please give an example)?

7. Have you ever heard about the rights of the Roma, Ashkali and Egyptians Communities? If yes, what legal documents you know that protects the rights of community and human rights in general?

8. Do you know what are your rights and responsibilities towards citizens? (Please list them with examples)?

9. If your right is ever violated from the community or the institutions do you know where you should ask for the support? 
10. What are your rights in decision-making aspect in your community?

11. Did ever happened that your rights are violated, in health, education, court, social welfare issues etc, (Please give an example)?

12. Do you know the institutions that protect human rights?

13. Did you ever heard about the UN Convention for the Rights of the Child?

14. If yes, do you know what it is?

15. If yes, do you know what the rights of child are? Can you list them some of the rights)?

16. What are your responsibilities as

17. Do you think that protection of the rights of the child at your community is at the satisfactory level?

18. What can be done do get improved/ change the situation?

19. Do the children know how to contact you in case they need your help?

20. What methods you apply when you work with children?

21. Do you have anything else that you might like to add?

\section{Questionnaire for the parents of RAE communities are as following:}

2. What do you understand with human rights?

3. What do you understand with children rights?

4. What is the basic human rights (how do you understand them)?

5. Do you think that your rights are violated and by whom? (Please give an example when do you think your right is violated and by whom)?

6. Do you think as a parent in the community has violated the right of you citizens (if yes please give an example)?

7. Have you ever heard about the rights of the Roma, Ashkali and Egyptians Communities? If yes, what legal documents you know that protects the rights of community and human rights in general?

8. Do you know what are the rights and responsibilities of your child? (List them with examples)

9. If your right is ever violated from any institutions, do you know where you should ask for the support?

10. What are your rights in decision-making aspect and what are the rights of your child in decision making?

11. Did ever happened that your rights are violated, in health, education, court, social welfare issues etc, (Please give an example)?

12. Do you know the institutions that protect human rights?

13. Do you think that children should have their rights?

14. Did you ever hear about the UN Convention for the Rights of the Child

15. If yes, do you know what it is?

16. If yes, do you know what the rights of child are? Can you list them some of the rights)?

17. What are your responsibilities towards your child?

18. Do you think that you are doing your best for your child?

19. What do you think is the most successful to discipline your child?

20. Do you know why your child is worried now?

21. Do you know what their wishes are?

22. If your child is abused/ beaten from an adult, how would you act?

23. Do you think that education is important? Why?

24. Do you have anything else you would like to say?

\section{Our methodology included the following:}

a. Analysis of written resources: Laws and regulations, communications, published articles, policy papers from official and unofficial sources.

b. Interviews with children, parents and team leaders from the RAE communities in 5 Kosovo regions: Peja, Gjakova, Ferizaj, Prizren and Fushe Kosovo 
The first chapter of the this report discusses the political and legal context of the RAE communities in Kosovo, engagement of the international and national organizations central and local government of Kosova in the implementation of legal policies that protects and promotes the Roma, Ashkali and Egyptian communities, their education and social inclusion.

Second chapter contains evaluation of the three target groups of children, parents and team leaders of Roma, Ashkali and Egyptians communities parents and leaders and children with specific focus on the knowledge of the UN Convention for the Rights of the child, knowledge of the children on basic human rights, institutions that protect their rights and service delivery including child participation and decision making, whilst from the children is asked to know the mindset and knowledge on their rights, their practical approach to the institutions in charge. Also it is required by the team leaders and the youth to see their engagement in the community, their support towards community and the children rights protection from the ground.

\section{Introduction}

Whatever you aspire, whatever you may do -

First feed the face and then talk right and wrong.

For even saintly folk may act like sinners

Unless they've had their customary dinners.

\section{Berthold Brecht, Die Dreigroschenoper}

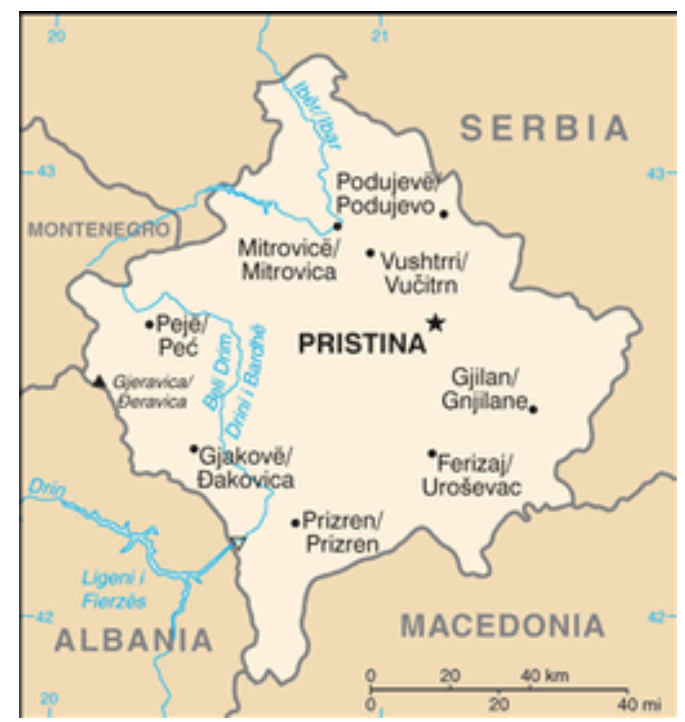

Fig 1. Kosovo map ${ }^{1}$

\section{Chapter}

The context of the minority rights and the engagement of government of Kosovo to implement the human rights legal framework and policies for the communities are considered quite necessary, and responsibilities of the local government are one of the key factors towards its implementation on the ground. Whilst the need for social integration of RAE 
communities was a political requirement of the EU to create the needed legal documents in power and designed in order to support proper implementation of the National and International legal policies and strategies for RAE inclusion in Kosovo, to be able to start the process of EU accession.

European Union, apart from dealing with economic issues, trade and prosperity it is also dealing with human rights in general. The concept of the human rights entered in the tractate of the establishment of EU. Therefore, human rights were elaborated in the tractate of the convention on the human rights and the basic rights which entered in to force in 1953.

In the all mentioned human rights forms, the most risked community in Kosovo society are (RAE) communities' 35,00040,000 members of Roma, Ashkali and Egyptians. Historical injustice deeply were applied while the damages of the infrastructure resulted from the war conflict 1999, created uncertain support for the communities, in health and social life. From the statistics of the year 2004 it showed that RAE communities of age 15-24 years old about $75 \%$ of men and $90 \%$ of woman were unemployed. Illiteracy was evaluated to be at $16 \%$. And one in 2 children lived with only 2 euros per day. EU Commission and Foundation for the Open Society has implemented a project on the integration of RAE communities in education, social and cultural society. ${ }^{1}$

\section{Political and legal context}

The Strategy for the Integration of RAE Roma Ashkali and Egyptians Communities, 2009-2015, was approved by the government of Kosova in December 24, 2008. The Kosovo Action Plan2for the implementation of the Strategy was presented in March 2010. In the introduction the Strategy is considered by the government as important instrument to achieve the fundamental goals, central to the realization of minority rights- participation, inclusion and fulfilling obligation.

In the context of the legal and policy developments for RAE communities, the Constitution of Kosovo was drafted, including specific measures of the Ahtisaari package. In addition to incorporating the international human rights documents within the Constitution, the Government of Kosova is pledged to use the affirmative measures in order to quickly improve the situation of the three communities. From the position of the European Union, implementation of the Strategy is the key element of the EU criteria for Kosovo to be able to start the process of EU accession. The REA Strategy was seen as important document for the implementation of the community rights in all related fields, education, child protection, cultural and social inclusion, as a feedback from the ministries in line with mandatory obligations to improve the social inclusion of the RAE communities.

\section{Responsibilities}

As the government of Kosova has taken on the overall responsibility to integrate Roma, Ashkali and Egyptian communities it follows that specific agencies of the government would be tasked with seeing to the realization of this objective. In fact there are a number of agencies tasked ${ }^{3}$. The specifics are divided between the ministries and municipalities. At the central level the responsibilities are divided between the local levels that directly are mandatory to work in line with the central level under responsibility of the Prime Minister's office, Office for Good Governance, Equal Opportunities, Human Rights and Gender Issues OGG, leading the Strategy technical Working group with the role to coordinate, share information's, formulate and prioritize the policies. Including in these goals are harmonizing government and donor investments, solving budget issues and preparing the biannual report on strategy implementation. This group includes senior civil servants and several agencies as European Commission liaison office, KFOS, From the local level- municipality level there are human rights units responsible to work with communities in the ground and try to solve the concerns of the communities from bottom level, in cooperation with Office for communities at the municipality level and other municipality level departments as education, health and social department.

\footnotetext{
1 Assistance of the EU for Kosovo, ( Assistance to the people in need)-www.delprn.ec.europa.eu 2 http:// www.aktion302.de/fileadmin/aktion302/kosovo-integration-RAE-2009-2015.pdf

$3 \mathrm{http}: / /$ www.ecmi-map.com/map/index.php?option=com_content\&view=category\&layout=blog\&did=35\&itemid=62@lang=en
} 
In the year 2010 EU has given the effort and proper support to ensure the education for all children of the communities in Kosovo and from the survey only $20 \%$ of the RAE communities do not have a single year of education. Only $4 \%$ finished obligatory elementary school of 9 nine years of schooling and $33 \%$ of RAE woman do not attend schooling at all. ${ }^{1}$

Even the Ministries from government of Kosova are committed to protect and promote the rights of the RAE communities, however obstacles and the concerns are presented among the children of the communities as the rights and the obligations by the government institutions itself are not applied to the community children. The institutions itself and Human Rights Units existing at the level of the municipalities and the main central level ones at the central level of ministries are obligated to monitor the communities in the regions and perform their obligations through the informative sessions either collaborate with the community Units at the municipality level and close collaboration should be applied also with the parents of the children from RAE communities and youth and the community leaders in general.

Finally, the Article 42 of the UN Convention for the Rights of the Child states that every individual should know for his rights according to this Convention, child or adult and the government should inform people about this Convention, whilst the articles 43-54 of the Convention state that governments and international institutions are obliged to work closely in order to implement the rights of the child.

\section{Key community issues}

I. Knowledge, Attitude and Practices of children and communities in relation to children rights and child protection II. Evaluation of the communities knowledge on existing services in case of violation of the children rights

\section{Chapter}

Evaluation of the questionnaire of Children communities regarding the knowledge and attitude on children rights,
child participation and their knowledge on existing services in case of violations of the children rights.

During the Survey with RAE- Roma, Ashkali and Egyptian children, it resulted that Convention for Children Rights is not known by the children from communities except some articles that will be described below. The survey shows that Convention for Rights of the Child is not implemented in terms of the knowledge, rising awareness, children participation and information's, by the institutional responsibility that protects and promotes their rights.

With the children from RAE communities of the age 8-14 the survey has been done starting with questions on the children rights, their importance in general asking from the children to describe through examples, what are the rights they don't have, whilst we got an answer from the child respondents that in $89 \%$ of the answers they consider that the rights of the child are only ,,learning process and playing”, whilst from $11 \%$ of the child respondents answers are that they „,do not know what are their rights". In the questions for what do they think about the rights they do not have, in $78 \%$ the child respondents answered that, their economy's situation as food, clothing, housing, etc. is something that they do not have whilst $22 \%$ of them don't know. In the question about the people whom they think they did violate their rights, in $53 \%$ of the child respondents answered that,, parents, friends or the others from the community did violate their rights", whilst $10 \%$ responded that,, this did not happened to them that the rights are violated" and 37\% among them say ",they don't know who has violated their rights". In the question who informed children about their rights and what are their rights, the response was that $90 \%$ of the children are informed about their rights from their teachers, whilst $8 \%$ among them are informed from their parents, whilst $2 \%$ of them have been informed from the „others in the community, as leaders, neighborhoods etc." regarding the question about what are the children rights and can they list them any, $89 \%$ among them answered that ," the child rights are schooling and play" and $11 \%$ of them ,they don't know at all'. In the question whom they told in case they rights are violated $74 \%$ of the respondents answered that they told to their "friends, and parents", $3 \%$ they say their "teachers, directors" and $23 \%$ of them they "don't know". In the question what they want to know about their rights, in $82 \%$ the answer was "to have good and improved economic life, including food, house, toys etc.", whilst $16 \%$ they did not answered to this question and $2 \%$ among them wanted "to know more about their rights". In the question about what people do they know to tell them in case their rights are violated, $89 \%$ of them they tell to their "parents", $3 \%$ to their "friends" and

1 Assistance of the EU for Kosovo, ( Assistance to the people in need)-www.delprn.ec.europa.eu 
$8 \%$ they "don't know". In the question that what are the issues that occupy the children at the day they were interviewed, they answered in $96 \%$ they "want to play with their friends and other relatives" but they don't explain anything more whilst, $3 \%$ of them they don't know and $1 \%$ among children declare that their "rights are violated". In the question if they have been abused or beaten ever or any of their friends is, how they will act, the response among the child respondents was that in $78 \%$ they "tried to stop the friends from the conflict", whilst $20 \%$ answered they "were not beaten or been in the conflict ever" and $2 \%$ among them they say that they "have invited the parents to solve the conflict". In the final question regarding their any wish they want to add at the end of questionaries' they expressed their wishes as they wanted to have economic life improvements as: proper food, house, toys, dress and creative centers for children.

\begin{tabular}{|c|c|}
\hline Questions for the children & Answers with \% \\
\hline What are the rights they don't have? & $\begin{array}{l}89 \% \text { learning process and playing } \\
11 \% \text { do not know what are their rights }\end{array}$ \\
\hline What do you think about the rights you don't have? & $\begin{array}{l}78 \% \text { economy's situation as food, clothing, housing } \\
22 \% \text { they don't know }\end{array}$ \\
\hline Whom they think they did violated their rights? & $\begin{array}{l}53 \% \text { parents, friends or the others from the community did } \\
\text { violated their rights } \\
10 \% \text { this did not happened to them that the rights are violated } \\
37 \% \text { they don't know who has violated their rights }\end{array}$ \\
\hline $\begin{array}{l}\text { who informed children about their rights and what are their } \\
\text { rights }\end{array}$ & $\begin{array}{l}90 \% \text { teachers } \\
8 \% \text { parents } \\
2 \% \text { others in the community, as leaders, neighborhoods etc }\end{array}$ \\
\hline what are the children rights and can they list them any & $\begin{array}{l}89 \% \text { the child rights are schooling and play } \\
11 \% \text { they don't know at all }\end{array}$ \\
\hline whom they told in case they rights are violated & $\begin{array}{l}74 \% \text { friends, and parents } \\
3 \% \text { their teachers, directors } \\
23 \% \text { don't know }\end{array}$ \\
\hline what they want to know about their rights & $\begin{array}{l}82 \% \text { to have good and improved economic life, including food, } \\
\text { house, toys } \\
16 \% \text { not answered } \\
2 \% \text { wants to know more about their rights }\end{array}$ \\
\hline $\begin{array}{l}\text { what people do they know to tell them in case their rights are } \\
\text { violated }\end{array}$ & $\begin{array}{l}89 \% \text { parents } \\
3 \% \text { friends } \\
8 \% \text { don't know }\end{array}$ \\
\hline $\begin{array}{l}\text { what are the issues that occupy the children at the day they } \\
\text { were interviewed }\end{array}$ & $\begin{array}{l}96 \% \text { want to play with their friends and other relatives } \\
3 \% \text { don't know } \\
1 \% \text { declare that their rights are violated }\end{array}$ \\
\hline $\begin{array}{l}\text { if they have been abused or beaten ever or any of their friends } \\
\text { is, how they will act }\end{array}$ & $\begin{array}{l}78 \% \text { tried to stop the friends from the conflict } \\
20 \% \text { were not beaten or been in the conflict ever } \\
2 \% \text { have invited the parents to solve the conflict }\end{array}$ \\
\hline any wish they want to add at the end of questionaries & $\begin{array}{l}\text { they expressed their wishes as they wanted to have economic } \\
\text { life improvements as: proper food, house, toys, dress and } \\
\text { creative centers for children }\end{array}$ \\
\hline
\end{tabular}

Table 1. Questions for the children and answers in $\%$

\section{Final conclusions}

From the evaluation perspective of the child questionnaire from Roma, Ashkali and Egyptian communities, we come up to the conclusions that Children Rights in the communities of Roma, Ashkali and Egyptians are not known in accordance to the UN Convention of the Rights of the Child. Children from these communities represent the issues as the important one, the needs for the improvement of the social economy, the proper food, housing and clothing, including the needs for play and toys.

After the rights for playing, children's focus was in the importance of education process as a very important one for their development. Requesting adequate services for their development was one the major approach of the RAE children. During the presentation of their knowledge usually children presented the human rights incorrectly and mostly mixing up with responsibilities. So they were not clear what a right is and what responsibility is, so mostly these were not clearly defined 
concepts in their minds. During the evaluation among the RAE children is noticed that children are not aware about the institutions at the local municipality level, considering all the time that parents are the ones who should know in terms of following and protecting their rights.

According to the UN Convention for the Rights of the Child, by the children respondents from the communities, the article 27 of the Convention is known. This article states the rights for creating sufficient living conditions for the satisfactory child development. Children from the communities have knowledge for the article 28 and 29 of the Convention as well, speaking for the education and their development through education, whilst the Convention states that the rights to education tries to develop the child identity and his capabilities as much as possible and to encourage children in respecting the rights and values of the other people. Children mention in the questionnaire that education is most important and everything related to the performance and questions brings up that the education is very important for them and their development. Children from the mostly known article of the convention have practically talked about the article 31 of the UN Convention for the Rights of Child. They mostly like playing and having creative centers in the communities and having desirable toys they always liked. This is relevant to the article 31 as it states that children have the right for fun, play and creative activities and free time. Apart from three articles mentioned above which are known by the children from the communities, other articles from 1-42 are completely unknown to children and they are not aware of them.

Children are also not aware about the responsibilities of government and international organizations that are bounded to closely work, in order to offer those rights to the children as is stated in the UN Convention for the Rights of the Child. Children are not aware about any central governmental level and responsibilities or local municipality level, whilst they have never had chance to meet people in charge to human rights protection and promotion, except in some cases at the Office for communities at the municipality level and international organization that closely works with communities.

In conclusion, children need to get educated accordingly and become familiar with all articles of the UN Convention on the Rights of the Child. This is a mandatory obligation for international organizations in collaboration with central and local levels of government to offer these children, proper education, knowledge on human rights and responsibilities through systematic and interactive education from pre-primary education and elementary schooling. The human rights education should be offered through pedagogical context in consultation with the authors who designed the materials for pre-primary and elementary education to include articles of the UN Convention for the Rights of the Child. It would be excellent approach to apply mandatory subject in children rights education in schools through the subject of choice. Materials for children rights education should be evaluated by experts and are suitable for the age of the children that they're dedicated to. Children should also be taught and get familiarized about the institutions that protect their rights in case of their endangerment, give children access and include child participation accordingly.

\section{Evaluation of the questionnaire of parents in the communities regarding the knowledge and attitude on children rights, child participation and their knowledge on existing services in case of violations of the children rights.}

Parents of the children in the Roma, Ashkali and Egyptian (RAE) communities have been surveyed through the questionnaire that target's two above mentioned objectives of the survey. Due to evaluation parents are questioned about their knowledge on human rights and the answer among questioned parents in $92 \%$ responded that are "economic conditions as stated and mentioned food, clothing, home and employment" whilst in $6 \%$ they respond that the human rights are "education and schooling" and in $2 \%$ they think that "life without violence and problems" is basic rights of all human beings. Among parent respondents on the question that what are the rights of the child $98 \%$ responded that the children rights are: "education" and $2 \%$ responded that the rights of the child are "life without problems and violence". In the question regarding that "what are the basic human rights" the answer was in $92 \%$ saying that it is "food, clothing and housing (good economic conditions") whilst in $8 \%$ they responded that are "schooling and education". In the question made to the parents regarding that, if ever they rights are being violated and if yes by whom, mostly the general answer was from schools, teachers, people from the working place, from their family relatives, husbands, mother in law, neighbor's etc. From this perspective we see that as children also the parents are occupied with economic rights and the above mentioned articles as stated for the children evaluation. Mostly are occupied with living conditions of life asking for improvement and considering that all of the rights are included in the above mentioned. In the question to the parents have they ever violated the rights of their child? $96 \%$ of parents responded that they "did not violate the rights of their child", whilst $3 \%$ considered that "maybe they violated the rights of their child in the occasions were the economic living conditions were poor". In the $1 \%$ of respondents of the parents responded that they "don't know" if they have ever violated the rights of their child. We 
do understand that from this point of survey there is a trust in the parent's conscience that mostly they did not violate the right of their child, but being not aware about the other articles of the UN Convention for the Rights of the Child, we cannot consider this tolerance as a truth, when from the parents response we see a poor knowledge for the rights of child. When in the other question about the knowledge for minority rights and the documents in power that protects the rights of minorities, from the parent respondents in $99 \%$ of cases they "never heard", whilst $1 \%$ "heard about it, but they have no idea about the documents in power that protects minority rights". In the question for parents what are the rights of the child responsibilities the answer were listed as following: $98 \%$ of parents think that "the rights of the child is schooling and they have no ideas about responsibilities", whilst in $2 \%$ think that "education is responsibility". Here we have a mixing of roles of rights and responsibilities; these two concepts should be divided and elaborated. This can be done through methodology of teaching human rights through the manual for parents and the clear picture can be framed in the way that it will later help parents in conceptualizing the rights and responsibilities and will be able to follow the changes of the attitudes of their child as well. In the question "where would parents search for support if their rights are violated by any institution", the answer was $77 \%$ they "will seek support from the police", $14 \%$ they "don't know", $5 \%$ "will seek for help from municipality" and 4\% that "it never happened that any institution violated their right". In the question that what are the rights in the decision making aspect, the answer from the parent respondent's was that $87 \%$ is the husband who decides and $13 \%$ is the whole family were the children have their participatory approach in decision making. This is a psychosocial question, the rights and responsibilities are not clear to the parents and their role is how they are used for the joint collaboration and participatory approach in the family. But, this does not give precise picture as there is no explanation or listed points either, the knowledge for human rights by the parents in general is limited. In the question were parents are asked for any violation aver happened by the any institution as health, court, education or social welfare (questions supposed to be listed in the row) but the answer was that $97 \%$ never happened, $2 \%$ has happened in education by the teachers, directors, and $1 \%$ from the court, social beneficiary application. In the question about the knowledge for the institutions that protect human rights, the answers were listed as following; $70 \%$ they don't know about the institutions, $12 \%$ think that is police, $6 \%$ think the office for communities in the municipality and $2 \%$ think that is ombudsman. In the question for the parents what do they think, are they doing the rights and the best thing for their child, the answer was that $78 \%$ think that they can't do the best for their child because of the poor economic conditions, whilst $6 \%$ they declare, that they do the best for their children but the economic situation made them dependent in realizing the wishes of their children. But $16 \%$ among them they are not aware if they doing the best thing for their children. In the question for the children in what do they think is the best to discipline their child $98 \%$ think that schooling and education is the best, whilst $2 \%$ think that communication and conversation with children help them to become more disciplined. In the questions for the parents in what do they think what for instance their children are worried about, the answer from parent respondents was that $97 \%$ think that their children worried about the proper food, clothing, home (economic situation in general), $2 \%$ worried about the nondiscrimination in schools, mentioning still stereotypes and pre judgments etc and $1 \%$ to avoid problems between their parents. In the question if the child is beaten or abused from the adult the situation would be solved by the parents through communication between them and abuser in $98 \%$ and if the relations are not established will try to find help with the police and $2 \%$ will be trying to find support in the office for communities at the municipality level. In the final questioned opinion by the parents why they think the school is important the answer was that the school is the only thing that can develop and oversee the brilliant future for their child. And finally parents added that improvement of economic situation is one of the important things to change those living conditions and lifestyle in the communities.

Questions for the parents

Knowledge on human rights?

What are the rights of the child?

What are the basic human rights?

Have they ever have violated the rights of their child?
Answers in \%

92\% responded that are economic conditions as stated and mentioned food, clothing, home and employment

$6 \%$ education and schooling

$2 \%$ life without violence and problems

$98 \%$ education

$2 \%$ life without problems and violence

$92 \%$ food, clothing and housing (good economic conditions)

$8 \%$ schooling and education

$96 \%$ did not violate the rights of their child

$3 \%$ maybe they violated the rights of their child in the occasions

were the economic living conditions were poor

$1 \%$ do not know

$99 \%$ never heard
Knowledge for minority rights and the documents in power that protects the rights of minorities 
What are the rights of the child responsibilities

Where the parents would search for the support if they rights
is violated by any institution
is violated by any institution

what are the rights in the decision making aspect

any violation aver happened by the any institution as health, court, education or social welfare

knowledge for the institutions that protect human rights

are they doing the rights and the best thing for their child

what do they think is the best to discipline their child

what for instance their children are worried about

if the child is beaten or abused from the adult the situation between them and abuser

why they think the school is important the answer would be solved by the parents through communication

$1 \%$ heard about it, but they have no idea about the documents in power that protects minority rights

$98 \%$ think that the rights of the child is schooling and they have no ideas about responsibilities

$2 \%$ education is responsibility

$77 \%$ will seek support from the police

$14 \%$ don't know

$5 \%$ will seek for help from municipality

$4 \%$ it never happened that any institution violated their right

$87 \%$ it's the husband who decides

$13 \%$ whole family were the children have their participatory approach in decision making

\section{$97 \%$ never happened}

$2 \%$ has happened in education by the teachers, directors

$1 \%$ from the court, social beneficiary application

$70 \%$ don't know about the institutions

$12 \%$ it's the police

$6 \%$ the office for communities in the municipality

$2 \%$ ombudsman

$78 \%$ can't do the best for their child because of the poor economic conditions

$6 \%$ that they do the best for their children but the economic situation made them dependent in realizing the wishes of their children

$16 \%$ are not aware if they doing the best thing for their children

$98 \%$ schooling and education is the best

$2 \%$ communication and conversation with children help them to become more disciplined

$97 \%$ children worried about the proper food, clothing, home (economic situation in general)

$2 \%$ nondiscrimination in schools, mentioning still stereotypes and pre judgments

$1 \%$ avoid problems between their parents

$98 \%$ if the relations are not established will try to find help with the police

$2 \%$ find support in the office for communities at the municipality level

the school is the only thing that can develop and oversee the brilliant future for their child

improvement of economic situation is one of the important things

to change those living conditions and lifestyle in the communities

Table 2. Question for the parents and their answers in $\%$

Evaluation of the questionnaire of Team leaders in the communities regarding the knowledge and attitude on children rights, child participation and their knowledge on existing services in case of violations of the children rights.

In the evaluation of the questionnaire by the Team leaders in the communities, we brought opinions of the team leaders knowledge on UN Convention for the Rights of the Child, their collaboration with institution, child engagement and participation in decision making processes as well as their access to communities', exploratory ideas for the networking skills and mediation and other cross activities that could be applied by the Team leader work support in the communities.

In the questions made to the Team leaders about what are human and children rights in general and what are the rights of the child the answer is in $86 \%$ answered that it's the democratic element of the equal opportunity of all human beings, whilst $14 \%$ responded that human and children rights are the freedom of thought, freedom of movement, freedom of expression, gender equality, right to religion, etc. In the question to the Team leader for what are their responsibilities toward Roma, Ashkali and Egyptian (RAE) communities all of them in 100\% of the respondents responded it's their responsibility in promoting the rights of community is respecting equal opportunities in the community, and the promotion and protection of 
the right of community through the human rights legislation in power. In the question if the Team leader right is violated ever and by whom, the response was mostly that now while there are documents and legislation on human and minority rights in power the discrimination facts are less and less, but till the legislation was not well established especially before and after the war of 1999 have had discrimination in the community. In the question if ever happened that team leaders have ever violated the right of citizen's, the response was that by the matter of awareness, they never violated the rights of their citizen's and among all respondents responded equally in 100\% saying that they did not violated the right of their citizen's. In the questions asking Team leader about their knowledge of the human rights policies for the rights of minorities they declared that they heard about RAE Strategy and Action Plan 2009-2015. They heard about the Constitution of Kosova and Ahtisari package that protects rights of minorities. In the question if the rights of the people from communities are violated, do the Team leaders know where they can direct the issue to support the communities in terms of minority rights, the answer is that they all know to direct issue to the community office at the municipality level, if issues are not solved they continue with other institutions as police, courts, ombudsperson. Whilst in the questions if it happened if the right is violated in health, education, court, social wellbeing and the answer among Team Leaders is that it usually did not happen but if it happens in some occasions such as the rights of children on education, the rights of minorities in the court or social beneficiary income, the Team leaders supported the communities when ever asked. When the Team leaders are asked about their knowledge on the UN Convention for the Rights of the Child the response was that in $100 \%$ they heard about this convention but they are not aware about the knowledge of the articles for the rights of the child either about any specific information regarding this convention except mentioning that this Convention protects all the rights of the child without precision in specifics and also consider that they were not been yet familiar about what the convention document contains. About their rights as Leader in the community they declared in $100 \%$ of respondent's that their role in the community is to protect the rights of the child rights of communities in general and toward education, equal opportunities for all, better life, social integration of communities. Regarding the question are they satisfied about the protection of the rights of the child in the community the answer was that partially are satisfied but it can be better, but they did not specified the obstacles and gaps. In the question for the Team leader about the knowledge of the children for their role in the community and do they call them for support in any asked situation, the answer was that, they all know about them and about they supportive role in the community. About the question in what methodology of action they apply to support children the answer among all leaders was that it depends on the situation or the problem they have but always bearing in mind that with children we apply pedagogical methodology from the level they belong but not being able to specify what are the methods they apply while working with children. The finally what the leaders would add for the end of the survey they committed themselves as moral obligation to support, promote and improve the community rights.

\begin{tabular}{|c|c|}
\hline Questions for the Team leaders & Answers in $\%$ \\
\hline $\begin{array}{l}\text { what are human and children rights in general and what are } \\
\text { the rights of the child }\end{array}$ & $\begin{array}{l}86 \% \text { democratic element of the equal opportunity of all human } \\
\text { beings } \\
14 \% \text { the freedom of thought, freedom of movement, freedom of } \\
\text { expression, gender equality, right to religion }\end{array}$ \\
\hline $\begin{array}{l}\text { hat are their responsibilities toward Roma, Ashkali and } \\
\text { gyptian (RAE) communities }\end{array}$ & $\begin{array}{l}100 \% \text { it's their responsibility in promoting the rights of community } \\
\text { is respecting equal opportunities in the community, and the } \\
\text { promotion and protection of the right of community through the } \\
\text { human rights legislation in power }\end{array}$ \\
\hline uestion if the Team leader right is violated ever and by whom & $\begin{array}{l}\text { now while there are documents and legislation on human and } \\
\text { minority rights in power the discrimination facts are less and less, } \\
\text { but till the legislation was not well established especially before } \\
\text { and after the war of } 1999 \text { have had discrimination in the } \\
\text { community }\end{array}$ \\
\hline $\begin{array}{l}\text { if ever happened that team leaders have ever violated the } \\
\text { right of citizen's }\end{array}$ & $100 \%$ did not violated the right of their citizen's \\
\hline $\begin{array}{l}\text { nowledge of the human rights policies for the rights of } \\
\text { inorities }\end{array}$ & $\begin{array}{l}\text { heard about RAE Strategy and Action Plan 2009-2015, heard } \\
\text { about the Constitution of Kosova and Ahtisari package that } \\
\text { protects rights of minorities }\end{array}$ \\
\hline $\begin{array}{l}\text { the rights of the people from communities are violated, do } \\
\text { e Team leaders know where they can direct the issue to } \\
\text { upport the communities in terms of minority rights }\end{array}$ & $\begin{array}{l}\text { direct issue to the community office at the municipality level, if } \\
\text { issues are not solved they continue with other institutions as } \\
\text { police, courts, ombudsperson }\end{array}$ \\
\hline the right is violated in health, education, court, s & it usually did not happen \\
\hline
\end{tabular}




\begin{tabular}{|c|c|}
\hline knowledge on the UN Convention for the Rights of the Child & $\begin{array}{l}100 \% \text { they heard about this convention but they are not aware } \\
\text { about the knowledge of the articles for the rights of the child }\end{array}$ \\
\hline Rights as Leader in the community & $\begin{array}{l}100 \% \text { their role in the community is to protect the rights of the } \\
\text { child rights of communities in general and toward education, } \\
\text { equal opportunities for all, better life, social integration of } \\
\text { communities }\end{array}$ \\
\hline $\begin{array}{l}\text { satisfied about the protection of the rights of the child in the } \\
\text { community }\end{array}$ & partially are satisfied but it can be better \\
\hline $\begin{array}{l}\text { knowledge of the children for their role in the community and } \\
\text { do they call them for support in any asked situation }\end{array}$ & $\begin{array}{l}\text { they all know about them and about they supportive role in the } \\
\text { community }\end{array}$ \\
\hline what methodology of action they apply to support children & $\begin{array}{l}\text { it depends on the situation or the problem they have but always } \\
\text { bearing in mind that with children we apply pedagogical } \\
\text { methodology from the level they belong }\end{array}$ \\
\hline what the leaders would add for the end of the survey & \\
\hline
\end{tabular}

Table 3. Question for the Team leaders and their answers in \%

\section{Final conclusions}

From the point of the survey for the Team leaders and their role in the community, we came to the conclusion that leaders are willing to support the community in any given occasion, mostly whenever asked. We cannot say that the self-conscience is not built, but the responsibilities toward children and communities in general should be brought and expanded in all related fields, starting from education, child protection, decision making processes and child participation. The limited knowledge for the UN convention for the Rights of the Child is an obstacle knowing that they heard about them but they don't know the articles and responsibilities of the children. Increasing the limited knowledge about the collaboration with networking activities, with human rights units at the municipality level, unit for communities and directorates for all related fields at the municipalities and government is needed and these are mandatory mechanisms established to integrate and protect the rights of communities.

Besides, the chain of links between children, parents and team lieders and youth it is the education process that needs to be explored and rights through education can be promoted smoothly.

Comparative perception among children, parents and team leaders in the Roma, Ashkali and Egyptian communities for the knowledge about the UN Convention of the rights of child and, knowledge on the institutional responsibilities and cooperation between the communities and child participation in decision making processes.

\section{Key community issues overall evaluation}

III. Knowledge, Attitude and Practices of children and communities in relation to children rights and child protection

IV. Evaluation of the communities' knowledge on existing services in case of violations of the children rights

Comparative evaluation of the children, parents and team leaders in the communities referring to the Chapter I and II key issues: - Their knowledge about the UN convention for the rights of the child and its articles.

- Their knowledge about an institution and services that protects and promotes community rights. 


\section{Knowledge about the UN Convention of Rights of the Child and its articles}

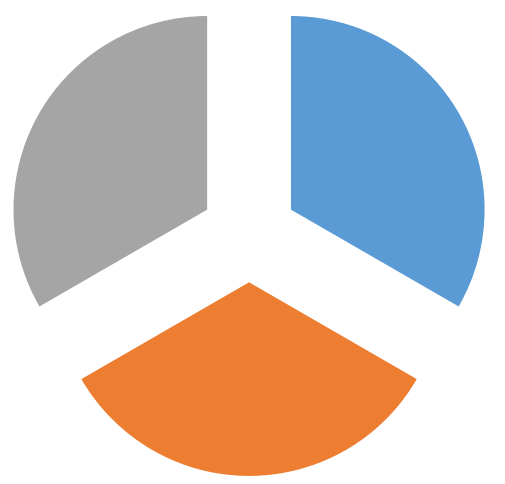

Children

Parents

Community

Fig 2. Knowledge about the UN convention for the rights of the child and its articles

In detail the figure above shows that all participants: children, parents and community have the same knowledge about the UN convention on the Rights of the Child and its articles and that knowledge is just hearing about it. They lack the knowledge of its articles, duties and responsibilities at the same level. They have no knowledge about the responsibilities that the international organizations and government have to protect their rights.

\section{When children rights are violated who do they turn to}

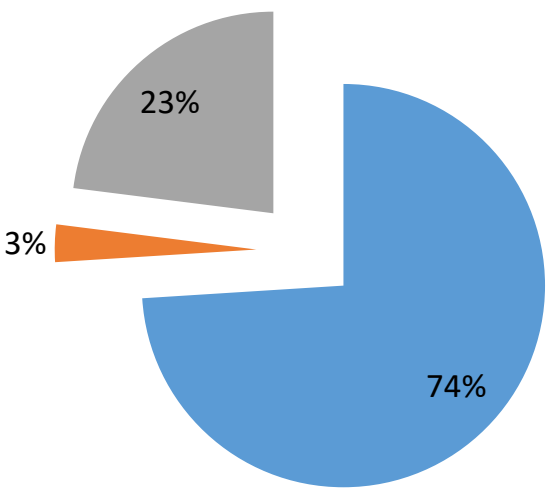

Parents \& Friends

Teachers \& Principals

Don't know

Fig 3. When children rights are violated they turn to? 


\section{When parents rights are violated they turn to}

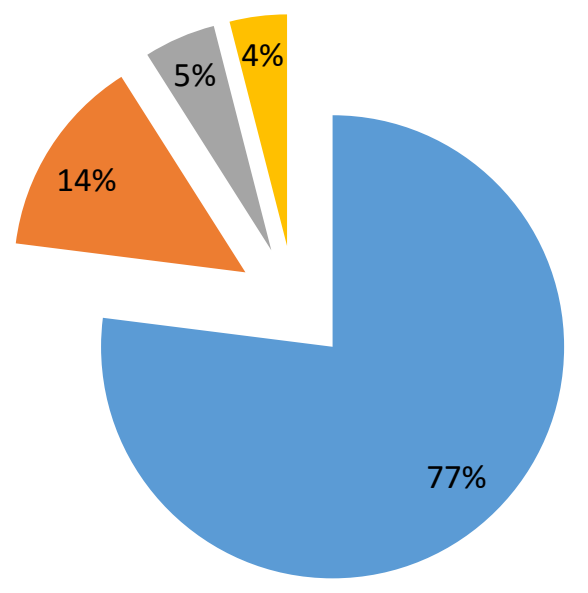

Police

Don't know

Office for the

Communities

Never happened

Fig 4. When parents rights are violated they turn to?

\section{When Team leader detect violations of community rights they \\ turn to ?}

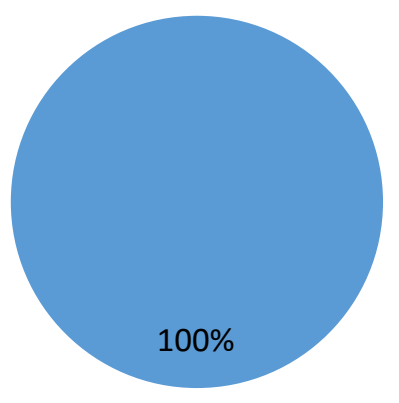

Municipality Office for the

Communities

Fig 5. When Team leaders detect violations of community rights they turn to?

Children's knowledge about the institution that protects and promotes the human, children and minority rights. 


\section{Children's knowledge about the institution that protects their rights}

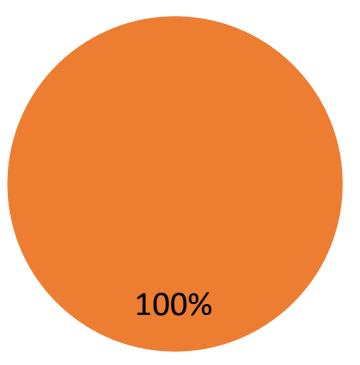

Parents

Fig 6. Children's knowledge about the institution that protects their rights

Children believe that only their parents know about their rights, and parents only know the Office for the Communities at the municipal level.

\section{Final recommendations}

The survey of the three targeted groups, the RAE children, parents and Team Leaders from the communities, brought a clear picture regarding the knowledge and attitude on children rights, child participation and their knowledge on existing services in case of violations of the children rights. During the survey all perspectives on the UN Convention of Children rights, are being evaluated in the quantitative manner bringing out there analyses on how children make a perception of parents and Team leaders in the communities. From the tables we could measure the exact approach of all three targeted groups in daily life. We could see their attitudes, their participation in decision-making and also their knowledge about the institutions that protect and promote children rights. From the evaluation we brought out the final conclusions that are required, measured that should be applied in order to change the way of thinking for all three targeted groups in terms of children rights and minority rights.

The gaps and obstacles presented in the survey brought in the clear picture of the situation and presented needs for the change will empower communities to work closely with institutions and respect the rights of the child in participation and decision-making processes. The UN convention for the Rights of the Child and its articles should be taught to all involved targeted groups, children, parents and team leaders and their engagement will bring positive climate in the minority integration in general. A number of recommendations has been requested in order to make positive changes in communities in above mentioned regions. The actions and activities will reach direct impact on changes and this will be easy measured by the end of activities that will be delivered by the national institutions, local ngo's and International organization's through different projects.

1. Provide basic trainings for the RAE children community on children rights and responsibilities through the materials designed for the children rights, while the articles of the UN Convention for the rights of the child are treated and developed through at the level of child's age. What is important in this context is that the books should be designed on behalf of the course- subject of choice that is free to be chosen from the regular schooling and this depends on the will of children and teachers. But considering the need for education on children rights and responsibilities the materials and the course can be recommended as well as a general course in accordance to the plan-programs and strategies for pre and primary education developed by the Ministry of Education.

2. Engage a professional teacher expert on children rights and responsibilities for the ages 6-12 who will lecture to the children in the communities after school sessions in the community centers in regular basis. The authors of the books should be teachers also, who can provide training courses for children and parents of RAE communities. 
3. Deliver basic trainings for the teachers and parents of the REA community on the human rights community rights in general and children rights and responsibilities in specific.

4. Design of 2 manuals, one for the teachers and one for the parents on the legislation package that protects the rights of the RAE communities. Considering the importance of the child education on children rights perspective, the knowledge on the rights and responsibilities cannot be taught only by teachers in the pedagogical way through the lecturing process but the whole education should be delivered also at home in order to create the sustained change in children's attitude towards knowing the rights and their responsibilities. Whilst, the manual for teachers is quite different as the professional capacities in delivering the human rights course needs considerable professional and pedagogical preparation in advance of the subject as currently we do not correspond with a such materials as they exist in other European countries. Since the books for education of children rights and responsibilities are in place and applicable only in some schools and preschool education in different regions of Kosova, applying it in the entire school system would be highly beneficial because it is a subject of choice in regular schools. The manuals can be designed by the same experts who already have applied for children rights education and responsibilities in line with the UN Convention for the Rights of the Child in these book materials. Considering that manual for teachers for teaching process is quite different from the one for the children, two manuals with different methodical approach should be designed in order to reach the overall goal for the community in awareness rising for the children rights and responsibilities. The one for lecturing process is quite different from the one for the parents.

5. Rising awareness activities with children from REA community through games, different artistic activities, etc, on the children rights and responsibilities.

6. Provide rising awareness campaigns about the legislation that protects RAE communities.

7. After the designed manuals, a voice recorded manuals should be provided on community rights on the legislation package that protects the rights of the RAE community to the parents of REA community that are illiterate in order to deliver the information among all RAE communities.

8. Basic trainings for the community leaders on human rights and the minority rights in specific. The importance of delivering those trainings are to empower the community leaders and the youth working closely with community, protecting their rights and being more closer to community in the support to their concerns on human rights violations. The importance of their closer collaboration and support to the community in any accrued situation is quite important as the lessons learned practices will be a greater support for the community at the advisory purpose. Knowledge on the human rights policies and minority rights in specific will increase the awareness for the community as well. Mediation activities are also of great importance between the community leaders, youth and the institutions and will establish closer networking for example with human rights units that are operational at the municipality level.

9. Cross line activities for the RAE children on the hygienic and sanitary principles and reproductive health care and health aid that can be delivered through the games on children rights and responsibilities.

10. Provide networking sessions between the human rights units at the municipality departments, community units at the local level and REA community NGO level with the course on the human rights in general and in specific about the rights for the communities.

11. Trainings for the task forces on human rights monitoring tools in support to REA communities.

\section{REFERENCES}

(UNCRC), United Nations Convention on the Rights of the Child

Reichert, E (2006) Understanding Human Rights, Exercised book, SAGE Publishing 1-4129-1411-6 
Thornberry, P. Estebanez,M.A.M (2004) ,, Minority Rights in Europe" Council of Europe Publishing, 92-871-5366-3

Butler, C. (2008) „, Human Rights Ethics” A rational Approach, Purdue University Press, Indiana 978-1-55753-480-4

Mason, Mc.D. Brien,L.E. Greene,E. (1991) „, Education towards a rights culture" National Institute for Citizen Education in the Law (USA) 9-780864-862-150

Osler,A. (2005) ,, Teachers Human Rights and Diversity" USA 978-1-85856-339-8

Osler,A. Starkey,H. (2010) ,, Teachers and Human Rights Education” USA 978-1-85856-384-8

(UNICEF), Child Friendly Schools Manual", USA 978-92-806-4376-3

KOSOVO, (2009) ,,National Strategy and Action Plan for the Rights of Child (2009-2013)"

KFOS, (2006) ,, Supporting Kosovo Policy-making towards European Integration”

KOSOVO, (2008) „,Summary of the Antidiscrimination Law and Administrative instruction Implementation”

\section{Internet References}

Assistance of the EU for Kosovo, (Assistance to the people in need)-www.delprn.ec.europa.eu http:// www.aktion302.de/fileadmin/aktion302/kosovo-integration-RAE-2009-2015.pdf http://www.ecmimap.com/map/index.php?option=com_content\&view=category\&layout=blog\&did=35\&itemid=62@lang=e $\mathrm{n}$ 